\title{
From Pandemic Control to Data-Driven Governance: The Case of China's Health Code
}

\author{
Wanshu Cong * \\ European University Institute (EUI), Fiesole, Italy
}

Current debates over digital contact tracing mainly focus on the tools and experiences in the West. China's health code, while often seen as one of the earliest and most widely adopted apps since the outbreak of COVID-19, has not been studied specifically. This article provides a detailed analysis of the health code, draws comparison with the contact tracing apps developed by Google and Apple, and seeks to understand the specifications and contradictions internal to the health code's development and deployment in China. Looking at both technical features and the mode and process of its adoption, the article argues that the health code is strictly speaking not a contact tracing tool, but a technology of population control which is integrated in traditional forms of control and facilitates the enhancement of such control. As a technology of ruling the population, rather than the virus as such, the health code also reveals crucial problems in the modernization and informatization of the state governance and public administration. A critique on the health code solely informed by privacy and personal data protection runs the risk of being co-opted by the government and technology companies deploying such tools to expand their surveillance and regulatory power.

Keywords: contact tracing, big data, privacy, surveillance, health emergency, digital platform

\section{INTRODUCTION}

Digital contact tracing has attracted enormous interest among policymakers and academics since the outbreak of COVID-19 (e.g., Mello and Wang, 2020; Morley et al., 2020; Taylor et al., 2020). Extensive debates over issues such as the effectiveness and accuracy of virus detection and concerns over privacy and discrimination have mostly looked at technologies and experiences in the West, especially the tools developed by Google and Apple ("Gapple"). The Chinese example-a smartphone-based digital program, known as the health code-while often appears in current discussions about digital contact tracing as one of the earliest and most widely adopted apps (e.g., Ienca and Vayena 2020; Kofler and Baylis 2020; Morley et al., 2020), has not been studied specifically. This article offers a detailed analysis of the health code, seeking to expose and understand its specifications and the contradictions internal to its development and deployment in China.

The Chinese health code represents an important experiment that both relies on and tests the promises of digitalization, and its adoption and normalization have implications both within and outside China. Some of the criticisms against digital contact tracing tools, for example, about privacy and mass surveillance, are extremely relevant to the health code. However, besides these general concerns, it is also necessary to develop a more socially specific critique, given the sociopolitical contexts of the health code and China's approach to pandemic control. A perspective that is both sensitive and critical to the Chinese social reality is needed to expel mythifications, clarify 
misunderstandings, and uncover implicit and unproven assumptions inside and outside China about the health code.

To develop such an understanding and critique about the health code, this article sets out to do three things. First, it contextualizes the health code in the situation of China's pandemic control to show the specific demands and the social and political conditions that have made its adoption possible. Second, it compares the functionality of the health code to the Gapple contact tracing apps to examine the governance logic underpinning the health code. Third, it investigates the legal and political environment during the rollout of the health code, focusing on the power dynamics between the government and technology companies and between different levels of the government and the interaction between technology and law. Together, the three aspects of the inquiry aim to better capture the health code as a site and product of complicated social construction, rather than simply an instrument or object of governance. Meanwhile, the limitation of this inquiry has to be immediately pointed out: the article does not address an obvious exclusive effect of the health code, i.e., the restrictions experienced by people who cannot use it because they do not have smartphones or Internet connection or do not have national IDs. To fully understand the social costs of the dominant "technosolutionist" approach to pandemic control (Milan 2020), how these "have-nots" have been treated and their needs dealt with should be critically studied in future research.

The article is organized as follows. It begins with a methodology section that explains how information is collected and the analytical framework used in this article. Then, in the sections China's Approach to Pandemic Control and the Emergence of the Health Code, the Health Code: Not Just Another Contact Tracing App, and Political and Legal Conditions of the Health Code, the article carries out the threefold analysis outlined above. The main arguments are that the Chinese health code should not be considered, strictly speaking, as a contact tracing tool, even less a tool that tracks the spread of the virus. Instead, the health code should be seen as part of a cluster of technologies that rule the mobility and activities of the population. As part of the technologies of ordering the population, it turns individual health and population's collective health into a new avenue of social control and converges surveillance with public service. Meanwhile, despite its function of social control, the health code is not an object external to political contestations. The patchiness of the health code and the difficulties of national unification and regulation reflect the interesting and complex struggles behind the superficial power synergies required by the Chinese approach to pandemic control. In the concluding section, the article reflects on the broader relevance of the case study of the health code for the discussion on data-driven governance and the state of exception.

\section{METHODOLOGY}

While substantive fieldwork is required for fully studying the health code, this remains challenging given the current pandemic situation. Accordingly, the research delves into official documents published by the Chinese government, information released in governmental press conferences, and secondary information, including reports and commentaries in Chinese and nonChinese news media and academic literature. The time frame of document collection is from mid-January to mid-July 2020. As will be seen, the health code has various names across the country and is often used as a shorthand name for various mini apps used in different locales. And there have been many other smartphonebased, QR code-generating apps used for tracking and managing people's movement. For the purpose of this research, only information about mini apps that assign individuals with colored QR codes to indicate personal risk levels is collected for analysis.

Given the pandemic situation and the political environment, some information from these sources, such as the number of registered users of the health code and the number of its scanning, is difficult to verify. And some critical information, for example, regarding the actual decision-making process of the government at different locales and levels concerning the rollout and regulation of the health code, remains missing. These limitations are addressed in two ways. First, to mitigate the consequences of the lack of verifiable empirical data, I gathered personal narratives about using the health code from Chinese social media platforms, such as Sina Weibo, WeChat, and Douban, and through informal conversations. These voluntarily generated narratives reveal people's perceptions and experiences and are read together with the published documents by the government and news media to illuminate multifaceted realities of the health code. Second, I read the materials from governmental sources and news media dynamically and symptomatically, by which I trace the evolution of governmental and public discourses about the health code and, meanwhile, look at not only what is said but also how things are said and what is unsaid. Such reading engages the health code as a constantly evolving object for critical inquiry, and it reverse-engineers the process of political decision-making. Admittedly, the arguments and conclusions of this article are inevitably speculative, but this methodology is currently suitable for initiating a socially informed understanding and critique of the health code.

The dynamic and symptomatic reading is driven by the research objectives mentioned earlier and, in turn, is informed by a particular analytical perspective. In this article, I borrow analytical tools and insights from science and technology studies, the literature on governance and governmentality, and the literature on the modern managerial state to interpret the collected materials. The analytical perspective considers datafication (as in the case of the health code) as a process of producing legibility and actionable knowledge for social sorting and social ordering (Scott 1999; Lyon 2005; Asdal et al., 2007; Davis et al., 2012) and draws attention to the coproduction between such knowledge and state power in China's digitally facilitated pandemic control, as well as to how this coproductive process involves a wide range of state and nonstate actors and social practices (Foucault, 1995; Foucault, 2007; Jasanoff, 2017; Jasanoff, 2004), to show the complex entanglement of politics, law, and social practice that both affects and is affected by the development and deployment of the health code. 


\section{CHINA'S APPROACH TO PANDEMIC CONTROL AND THE EMERGENCE OF THE HEALTH CODE}

The overall strategy of controlling and preventing the spread of COVID-19 in China can be summarized as mass social mobilization under the general rhetoric of patriotism and collectivism. For example, since late January, the Joint Prevention and Control Mechanism of the State Council ("JPCMSC") has stressed to "strengthen society-wide efforts to prevent and control the epidemic” (群防群控) (JPCMSC 2020a). Expressions such as "grid and blanket management" (网格化, 地 毯式管理), "be accountable and fulfill the duty of defending the territory” (守土有责, 守土尽责), and “a people’s war against the epidemic" (全民战疫) are commonly seen in official statements and propagandas (JPCMSC 2020; Xinhua News Agency 2020; Song and Xu, 2020; China Daily, 2020, 2). The health code is a product of this overall strategy and appears to address several challenges of pandemic control in China. At the beginning of the COVID-19 outbreak (around the time of the Chinese New Year), measures of mass immobilization were adopted across the country, including the disruption of interregional traffic, the notable lockdown of hard-hit areas, and the so-called close-off management of residential clusters. Such drastic and sweeping measures soon appeared unfeasible and economically unsustainable. On February 2nd, the JPCMSC called for all departments of all localities to enhance "scientific epidemic control" and to organize the resumption of work and production "by categories and in batches" (JPCMSC 2020d). The need for delicate balance and coordination between economic recovery and epidemic control, in turn, required more precise and fine-tuned tools to speedily track the spread of the virus and monitor the population's health states at a greater scale.

Meanwhile, under the scheme of mass social mobilization, a huge number of state staff, party members, and community workers were deployed for the day-to-day operation of epidemic control. Despite the speed of state-led organization and the scope of participation, anti-COVID operations at the grassroots level were far from being efficient and orderly. Despite the employment of high-tech devices, such as surveillance cameras, infrared thermodetectors, and drones, most of the anti-COVID work remained manpowered. For example, in local communities, the so-called "grid management" often involved home visits, issuing temporary movement passes to residents in residential clusters, collecting residents' information through interviews, and creating health profiles for each household (JPCMSC 2020a). These daily monitoring and tracing measures often required close human-tohuman interactions, which not only incurred repetitions, redundancies, and errors but also increased the chances of virus

\footnotetext{
1"Grid Management" means to divide jurisdictions of grassroots self-government into grid patterns and connect them into informatization platforms for more precise management and inspection (Ran, 2019). The idea was first brought forward by the Communist Party in the third Plenary Session of the 18th CPC Central Committee in 2013, under the rubric of "improving methods of social governance" (Central Committee of the Communist Party of China, 2013, para. 47).
}

transmission (Tang et al., 2020; Chen 2020). These shortcomings of manual monitoring methods became more severe after the Chinese New Year when large numbers of people started to travel crossregion to get back to work.

In addition to the practical difficulties of daily anti-COVID operations, the strategy of mass social mobilization has resulted in some serious negative consequences that led the JPCMSC to call for scientific epidemic control. At a time when political pressure was extremely tight and the rhetoric of war was commonly used, mass mobilization easily led to the blurring between legal and illegal and the sidelining of principles of necessity, proportionality, and accountability by local authorities. For instance, a large amount of personal information of people originally from Wuhan collected by community and neighborhood workers was released to the public on social media; some residential districts expulsed people traveling from Hubei; and some public roads and highways were dug up by villagers without authorization to block traffic routes (e.g., Privacy Guardians, 2020; Sun 2020; Xiaoshan 2020). These incidents suggested not only conspicuous disrespect for human rights and the rule of law by authorities and staff at the grassroots level but also a hysteric collective panic both reacting to the epidemic and instigated by the rhetoric of war. To redress these problems, it became hence necessary to switch to methods that would appear scientific and objective to better tame the society's own response to COVID-19.

These circumstances created a unique opportunity for the Chinese digital platforms, notably Alibaba and Tencent, to intervene. To be clear, before the creation of the health code, the government has already decided to "make full use of the advantages of digital technologies and big data" to early detect the coronavirus and enhance the precision of antiepidemic work (JPCMSC 2020a; Ministry of Civil Affairs et al., 2020; JPCMSC 2020b). The health code was one of the tools delivered by the digital platforms following the government's overall strategy. In addition, under a responsibility system introduced by the government to back up mass mobilization (by which all governmental organs, enterprises, public institutions, local communities, and individual households shall take responsibilities for preventing and controlling COVID-19) (JPCMSC 2020c), digital technology companies also bore the responsibility to direct their resources and capacities to the societal anti-COVID efforts.

\section{THE HEALTH CODE: NOT JUST ANOTHER CONTACT TRACING APP \\ Functionality and Technical Specificities of the Health Code}

The health code first appeared in early February in Hangzhou and Shenzhen, home bases of Alibaba and Tencent, respectively. In Hangzhou, the municipal government believed that the resumption of economic activities should take advantage of the city's strong digital economy and requested Alibaba on February 6th to develop a smartphone-based health code program for employees returning to work in the city (Hangzhou Daily 2020a). Alibaba's health code went live within only four days. In Shenzhen, Tencent also launched its health code on February 9th. In both cases, the 


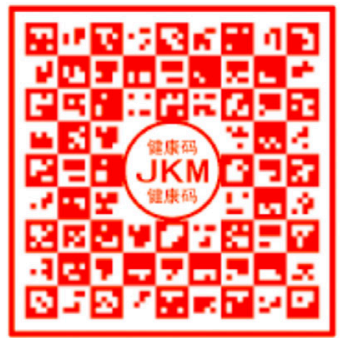

红码 (颜色值 $\#$ FB382D)

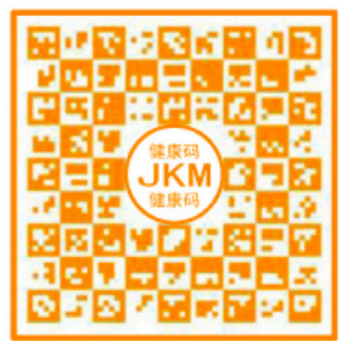

黄码 (颜色值 $=F F 8 F 1 F$ )

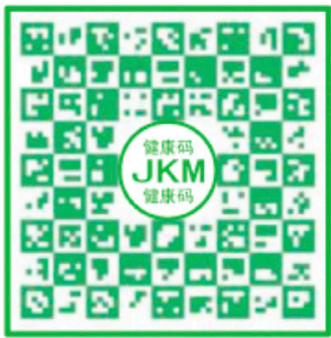

绿码 (颜色值 $\# 57 \mathrm{AC} 6 \mathrm{C}$ )

FIGURE 1 | Colored QR codes of the health code standardized by the GB/T 35723-2020 Information Security Technology-Personal Information Security Specification.

health code was a mini app embedded in Alipay and WeChat (hence, no need for separate downloading). In a few weeks after the initial experiment in Hangzhou and Shenzhen, over 200 cities were claimed to have partnered with these two digital platforms and major ICT service providers in China and adopted similar programs in respective jurisdictions.

Turning to the basic functionality of the program, a user searches the health code mini app used in her city (or province) through either Alipay or WeChat, registers on it, and is required to provide personal information, including names, national ID numbers, home addresses, health records, and travel histories of the past 14 days. Based on the information submitted by the user as well as data collected from public services, such as public transport systems, ICT providers, and hospitals, ${ }^{2}$ the health code program calculates the level of virus risk and assigns a colored QR code to each individual (Figure 1). The green code allows for unrestricted movement; one-week quarantine is imposed on people receiving the yellow code and two-week quarantine on those having the red code. Those put under quarantine are required to update their health information on the mini app every day. A user having the yellow code has to report her health state as normal on the mini app for seven consecutive days in order to receive a green code. Fourteen consecutive days of such reporting is needed for a red code to turn green. The colors change based on constant risk assessment and expire after a certain number of days. Hence, users having the green codes also need to regularly report on the mini app before the codes become invalid.

Having registered on the health code, people are required to scan or display their codes when going to public spaces or taking

${ }^{2}$ It is not clear what exactly the data sources are. According to a recommendatory national standard for the reference mode of health code published at the end of April, the data collected by the health code include, but not limited to data of confirmed and suspected COVID-19 cases; data of people having close contacts with COVID-19 cases; medical testing data; data from fever clinics; risk level of places where personal mobile devices have roamed over a particular amount of time; travel information; data from customs and border control; information about epidemic-hit communities and places of major activities; health profiles extracted from population health information platforms; data collected from community examinations and from various checkpoints; self-reported information. See Chinese National Standardization Administration (2020b), 11-12). public transport. For example, passengers taking the metro need to scan their health codes when boarding and rescan them when getting off. During the epidemic outbreak, some cities deployed anti-COVID staff to each metro car and each bus to ensure that passengers scanned their codes properly (Jiao et al., 2020). In residential communities, these QR codes have also soon replaced the paper passes. Residents and visitors need to show or scan their codes and have their temperature checked before entry. In the early period of the outbreak and in hard-hit areas such as Wuhan, scanning was often required. For example, many restaurants posted their own QR codes at the entrances, and customers needed to scan the restaurants' codes first in order to display their health codes. By scanning the codes at the restaurants or metro stations, the health code program also recorded the person's movements. The idea was that, with the system of real-name registration and constant collection and update of information, the health code could enable epidemic detection and intervention at the earliest stage, while increasing the efficiency of daily monitoring of population health and contributing to economic recovery (Jiao et al., 2020). As the epidemic slowed down in China since late April and early May and measures began to loosen, many places no longer require scanning-and-showing. Simply displaying the QR code to anti-COVID or security staff would suffice.

Since its adoption, the health code has been widely used in various sectors for monitoring and regulating the movement of the population in China. For example, the health code has been used for the so-called "point-to-point," "closed circuit" management ${ }^{3}$ of people returning to work and school. Since the end of March, people from Hubei going to Beijing needed to register and report on the Jing Xin Xiang Zhu mini app (京心相 助, the health code used in Beijing), have their information verified by their residential communities in Beijing, and get their travel requests approved (Beijing Daily, 2020). In addition to domestic movements, the health code has also

\footnotetext{
${ }^{3}$ Under the so-called "point-to-point," "closed circuit" management, people traveling from A to B have to report to the anti-COVID staff in A and B, be led by designated staff and follow specific travel routes so that the whole trips are constantly monitored. This type of management has been used for organizing trips of domestic migrant workers and returning Chinese expats. See Xiang (2020).
} 
been used to manage Chinese expats returning from abroad (China Civil Aviation Administration and China General Administration of Customs, 2020). Such swift and sweeping implementation gave the health code a quasicompulsory character. To be clear, this is not to say that there is a clearcut and specific legal obligation to use the health code in China. Legal responsibility can indeed occur when a person refuses to cooperate with governmental staff implementing epidemic control measures, but simply not using the app does not on its own create legal responsibility (JPCMSC 2020c). Rather, people in China are compelled by practical necessities to opt in as many essential daily activities are conditioned by it, such as going to schools, getting groceries, taking buses, and visiting families. This quasimandatory character hence is both a condition and a result of the comprehensive integration of the health code in Chinese epidemic control.

With respect to the technicality, the health code is different from the Gapple-led apps, which use the Bluetooth technology for contact tracing. The health code uses algorithm and big data technologies: the colors are determined by risk assessment using both information submitted by individuals and data from public service providers and base locations. This technological feature, translated into the methodology of epidemic control, means that the health code is not an app that tells you if you have had a close contact with someone diagnosed with the coronavirus. Rather, it analyzes various kinds of data to assess the possibility of the occurrence of close contacts and the likelihood of contracting the virus through such possible contacts. The function of the health code, essentially about individual and population profiling, hence, suggests a doubling down on the preventative logic, intervening even before the actual occurrence of close contacts.

These technological and methodological features are critical for understanding and evaluating the health code. The Chinese health code program and the Gapple-led contact tracing apps share the problem of lacking efficacy proofs, but for different reasons. With respect to the Gapple-led tools, at the technical level, they rely on the Bluetooth technology, whose capacity of signal detection remains questionable (Cellan-Jones and Kelion, 2020; Lee, 2020; Zastrow 2020). At the level of implementation, the problems with evaluating their effectiveness are, first, the lack of enough population downloading and using the apps and, second, the lack of information-sharing (if not centralization) to gather sufficient statistics to assess chances of false positive/negative (Fraser et al., 2020; Hinch et al., 2020). These problems, on both technical and implementation levels, are irrelevant to the Chinese health code: the health code does not rely on the detection of Bluetooth signals; it has a huge amount of users in China, due to its quasimandatory character and societal scale of adoption, and the data are collected and held by different levels of the government. ${ }^{4}$ So, at least locally and sectorally based statistical

${ }^{4}$ According to an official instruction, informatization products of community epidemic control should, in principle, be centrally deployed and used at prefecture (county, city. and banner) and above levels and can be deployed by subdistricts (in townships) and urban-rural communities if necessary (Ministry of Civil Affairs et al., 2020). analysis on efficacy is not impossible if evaluation at the national level is not yet feasible.

However, the health code has its specific difficulties of efficacy assessment. With respect to the technicality, as it uses big data analytics, the quality of data massively collected and the hypothesis underpinning the algorithm become crucial to understand and examine the results it gives. The lack of information on these two critical questions poses enormous hurdles to assess the effectiveness of the health code. Moreover, the doubly preventative logic of risk assessment creates additional critical difficulties: as the health code does not detect actual occurrences of close contacts but a person's overall virus risk level, its color assignation based on risk calculation is basically unfalsifiable, especially without knowing the hypothesis and data used in the algorithm. It is hence reasonable to see the health code's profiling as another "black box" process with little transparency for external quality check. At the implementation level, as a result of mass social mobilization, the systemic and comprehensive integration of the health code in a whole bundle of formal and informal surveillance and control apparatus makes it difficult to single out the health code as such and evaluate its role independently in the control and prevention of COVID-19.

\section{Understanding the Lack of Efficacy in Actual Practice}

The lack of both ex ante impact assessment and ex post efficacy studies stands in stark contrast with the speedy and comprehensive adoption of the health code in China's pandemic reactions. On the one hand, this contrast demonstrates the lack of prudence and accountability of the government going "all-out" to fight COVID-19. On the other hand, as the health code is not strictly speaking a contact tracing tool, a perspective other than virus detection and tracking is needed for understanding its "usefulness." Instead of judging and critiquing the health code from the perspective of scientific accuracy, a more helpful way of understanding this program is to see it as a part of the technologies of ruling the population and the society, rather than addressing the coronavirus as such. Controlling the epidemic, no doubt, requires monitoring and imposing certain restrictions on the population. The question is whether the measures are strictly necessary and targeted against the virus or are used to deal with the actual and perceived social consequences associated with the epidemic. Closely combined with the manpowered surveillance and control measures, the health code is a technology through which the power of ordering people's mobility and activities is exercised and relayed in daily encounters. For example, in mid-March, Shanghai's health code program provides group health QR codes for companies to post on their entrances. Employees and visitors need to scan the group QR codes with their smartphones and have the companies check and keep a record of their health states (Shanghai Bendibao, 2020). In Hangzhou, health certificates extracted from the health code mini app are obligatory for particular professions such as those working in restaurants, hotels, swimming pools, food production, and beauty salons and those working with children 
(Hangzhou Daily 2020b). The health code has also been used in recruitment processes. In Haikou, for instance, the recruitment of teachers by the city's education department includes written and oral exams. For both exams, the applicant needs to register on the provincial health code and report on it for 14 consecutive days before the exams. Anyone having a red code needs to provide the negative result of a nucleic acid test taken within seven days before the exams (Haikou Education Department 2020).

The "usefulness" of such a technology, hence, lies not in its accuracy and reliability but simply in its being used at a societal scale. By making people's health legible with colored codes, the health code transforms health into an avenue for various social control and discipline. This "usefulness" of the health code vividly reflects what the discourse of "technological empowerment" in the Chinese context actually implies: upgrading and amplifying tools to enhance the capacity of existing disciplinary powers (both governmental and nongovernmental), meanwhile making both individuals and the population more susceptible to measurement and control.

In addition to such paternalistic "technological empowerment," it is important to highlight the reliance on self-reporting: the information that the health code collects is partially submitted by users who need to update regularly to keep their health code valid. The involvement of individuals, even just as a matter of formality, transforms the power exercised by these institutions into individual self-discipline, producing a more fine-grained and covert form of control, internalized by every user. However, at the time of the epidemic outbreak, when everyone can potentially carry the virus and infect other people, this internalized form of control also helps individuals develop a sense of collective responsibility, solidarity, and security. To a certain degree, the strategy of mass social mobilization, as well as the collectivist culture and political conditions, forges a social consensus that every individual bears the responsibility to implement antiCOVID measures, such as self and mutual monitoring. Moreover, the sense of security obtained through the health code is a result of the convergence of population surveillance during the epidemic outbreak and the offering of essential social services. For example, as the health code information is shared with the local anti-COVID staff, people having the yellow or red codes would be regularly checked by community workers. The purpose of home visits is to ensure not only that they strictly observe quarantine requirements but also that their basic needs, such as food and medicines, are provided. Some community workers also provide psychological counseling for people under quarantine (Tang et al., 2020; China Daily, 2020, 4). In addition to monitoring in local communities, the health code has also been further attached to the e-platforms of local governments' public services. The Hangzhou health code was linked to citizens' electronic health cards and social security cards; residents can

${ }^{5}$ Chinese scholars discuss technological empowerment as a way of transforming the traditional relations between the governor and the governed to a more dynamic and information-based model of governance and a way of enabling more efficient interactions of different social actors in the state governance by taking advantage of the massive information collection and flow. See Guan et al. (2019).

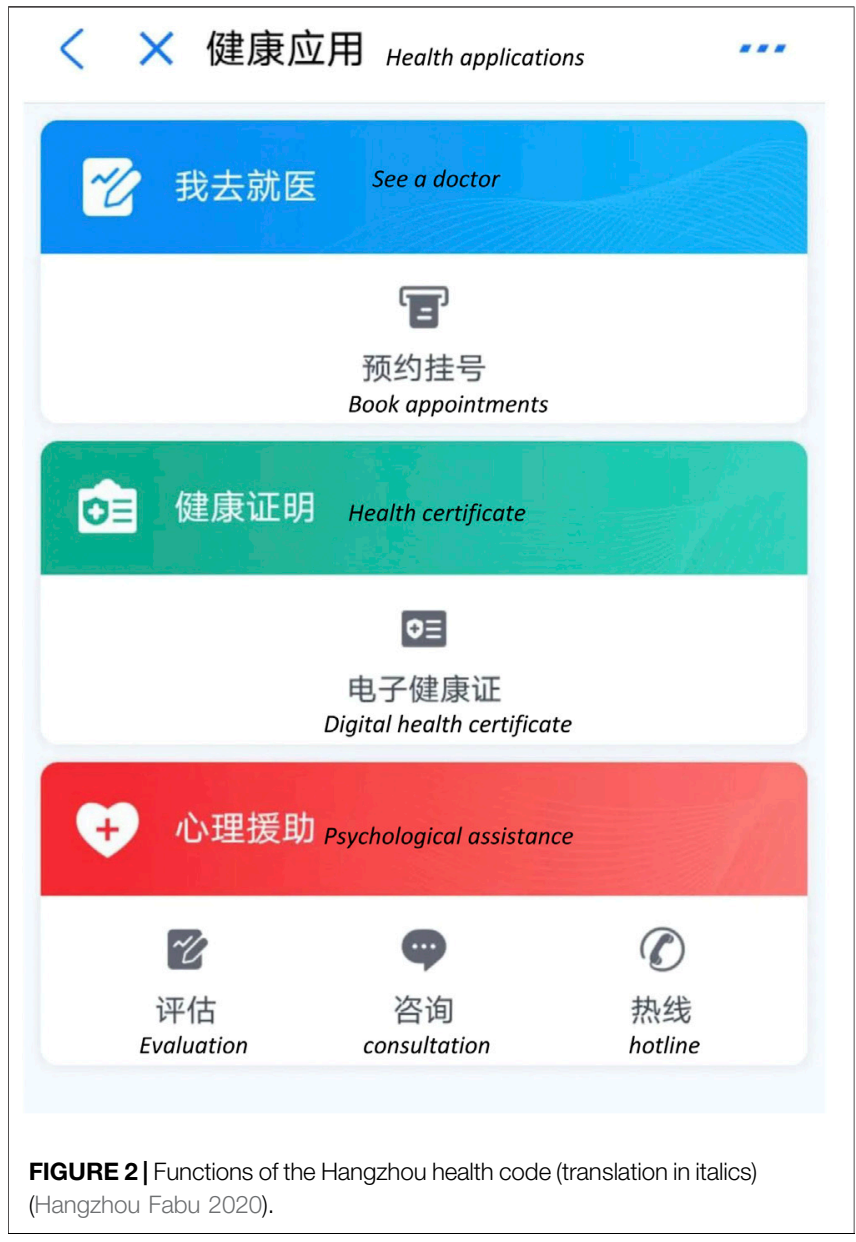

book appointments with doctors and get psychological assistance through the mini app (Zhan, February 23, and Figure 2). Therefore, by mixing mass surveillance and public services (even making the former a precondition for the latter), individuals' regular self-reporting through the health code, while subjecting themselves to the deepened control of various formal and informal authorities, also ensures that they are "protected" and looked after.

To sum up, the health code can be seen as one of the tools that produce what Scott describes "legibility and simplification" that is required for large-scale administrative ordering (J. C. Scott 1999). Meanwhile, top-down, societal imposition of the health code is conjoined with individual internalization, with the purpose of making the society and population more manipulable for controlling the pandemic and other associated social uncertainties. The health code both manifests and facilitates the transformation of governance-governance "empowered" by digital technologies - in the Chinese society: i.e., enhancing the power of population and society control by making individual and population health legible and meshing together mass surveillance and basic public service provision. As a technology of ruling the society and population, it is not only difficult but also misleading to assess its efficacy and usefulness in terms of virus detection and tracking. 


\section{POLITICAL AND LEGAL CONDITIONS OF THE HEALTH CODE}

While the health code emerged from the ostensible necessity of COVID-19 prevention and control, it is also situated at a sociopolitical conjuncture that has made ideas such as the health code easily acceptable and implementable in China. As discussed earlier, the health code is seen as a technology of social and population control that is fused with public service provision. This, then, puts the health code in a larger process of governance modernization in China, of which informatization plays a key part. The health code, in turn, also represents a unique chance of integrating and redistributing social resources for governance modernization. The development and deployment of the health code during COVID-19 are suggestive of some general issues regarding the transformation of state governance, such as the public-private and central-local power dynamics and the role of law.

\section{The Power Dynamics Surrounding the Health Code \\ The Public-Private Partnership in the Pandemic}

It is not unexpected that Chinese technology companies, notably Alibaba and Tencent, have played a major role in the health code. Over the past decade, Alibaba and Tencent have provided not only the platforms for Chinese e-commerce but also functions of social-networking, digital currency, and mobile payment, as well as various financial products and basic public services. In providing these essential services, they collect enormous amounts of users' data and exercise far-reaching power of restructuring people's lives (at least the urban residents). Meanwhile, a symbiotic and collaborative relationship has been forged between the digital platforms and the government (Zhang, 2020, 124). It is, hence, unsurprising that, to deal with an epidemic in a society that is increasingly datafied and digitally connected, these platforms would play an important facilitative role. This is indeed what the Hangzhou government had in mind when asking Alibaba to develop the health code for the returning workers in the city. The huge market share of Alipay and WeChat, as well as their real-name registration systems, is the primary consideration when the government decided to work with these two platforms to promote and implement the health code (Xu 2020).

As discussed earlier, the mass mobilization strategy is supported by a responsibility system that imposes antiepidemic obligations on every entity in all social sectors. Technology companies are hence mandated by and under the leadership of the government in the development and promotion of their digital anti-COVID tools. This public-private relationship, both in reaction to COVID-19 and a result of years of close alliance between the government and digital platforms, shows a different picture from those countries where Gapple asserted a more dominant role (Scott et al., 2020; Veale 2020, 38). However, as a result of the technical resources and expertise of datafication and informatization of the Chinese digital platforms, their role is far from being secondary: the process of building the technical framework of the health code was heavily reliant on Alibaba and Tencent.
Tencent led the drafting of the Reference Architecture and Technology Guide of Anti-Epidemic Pass Code, which was published by Shenzhen Standards Promotion Council on March 6 as industrial standard. Tencent's guide specified the data sources, methods of data collection, functions and technical requirements at different terminals, and the protection of personal data (Shenzhen Standards Promotion Council, 2020). In Hangzhou, Alibaba was involved in the drafting of the Guide to Management and Service of Hangzhou Health Code, published by the city's market regulation administration on April 9. The guide set out procedures of the application and the assignment of the health code, rules regarding its daily services and its use in the management of emergency response, and principles of information security (Hangzhou Market Regulation Administration, 2020).

Both companies have also participated in the national standard setting for the health code, initiated by the Chinese National Standardization Administration in mid-April (China Electronics Standardization Institute, 2020) (Table 1). Three recommendatory national standards were published on April 29 , addressing, respectively, the reference model, data format, and application interface of the health code (Chinese National Standardization Administration, 2020b; Chinese National Standardization Administration, 2020c; Chinese National Standardization Administration, 2020d).

As Chinese digital platforms have already been widely integrated in state governance, the close collaboration between the government and digital platforms in developing the health code further blurs the boundary between the public and the private. This affinity and obscurity between the public and the private in China can also be attributed to the relative lack of criticism and skepticism against digital technologies developed by Chinese tech companies. Unlike European countries, for example, where privacy concerns were raised almost like a knee-jerk reaction to proposals about contact tracing apps, the health code underwent far less scrutiny: only recommendatory industrial standards, with the significant input of digital platforms, are in place.

While the government harvests the technological benefits of the Chinese digital platforms to control COVID-19, the engagement of these companies in epidemic control indeed raises questions. In the name of fulfilling the social responsibility of fighting COVID-19, the epidemic becomes an opportunity for Alibaba and Tencent to embed themselves more deeply in people's daily lives. They also more closely conjoin with other governmental, social, and private institutions, which exercise disciplinary power over individuals and the population, further transforming the apparatus of state governance. What Christian Veale has observed with respect to Gapple-led apps-that both extractive and protective infrastructure is heavily reliant on a few digital platform monopolies-resonates in China, too (Veale 2020, 39).

\section{The Central-Local Relationship}

While the health code is commonly discussed as the digital tool that has been mandatorily used in China, a closer look into its development and implementation shows that there is not yet a single health code program consistently adopted throughout the country. And the role of the national government in adopting and 
TABLE 1 | Standardization plans collated by the Chinese National Standardization Administration on April 16, 2020 (Chinese National Standardization Administration, 2020a).

\begin{tabular}{|c|c|c|c|c|c|c|c|}
\hline & $\begin{array}{c}\text { Plan } \\
\text { number }\end{array}$ & Project name & $\begin{array}{l}\text { Nature of } \\
\text { standard }\end{array}$ & $\begin{array}{l}\text { Revise or } \\
\text { establish }\end{array}$ & $\begin{array}{l}\text { Competent } \\
\text { department }\end{array}$ & Centralizing unit & Drafting unit \\
\hline \multirow[t]{3}{*}{1} & 20201838- & Personal Health & Recommendatory & Establish & Standardization & National Information & E-government Office of the General \\
\hline & T-469 & Information Code- & & & Administration of the & Technology & Office of the State Council, China \\
\hline & & Reference Model & & & People's Republic of & Standardization Technical & Electronics Standardization \\
\hline 2 & $\begin{array}{c}20201839- \\
\text { T-469 }\end{array}$ & $\begin{array}{l}\text { Personal Health } \\
\text { Information Code- } \\
\text { Data Format }\end{array}$ & & & China & Committee & $\begin{array}{l}\text { Institute, First Research Institute of } \\
\text { the Ministry of Public Security of } \\
\text { PRC, Tencent cloud Computing }\end{array}$ \\
\hline \multirow[t]{4}{*}{3} & 20201837- & Personal Health & & & & & (Beijing) Co., Ltd., Alibaba China \\
\hline & $\mathrm{T}-469$ & Information Code- & & & & & Co. Ltd., Alibaba \\
\hline & & Application & & & & & \\
\hline & & Interface & & & & & \\
\hline
\end{tabular}

promoting it seems less dominant than expected. As discussed earlier, the health code was initially a local experiment and soon got traction across the country. The city-led initiative reflects a certain level of discretion enjoyed by local authorities when deciding and implementing locally specific policies to tackle COVID-19. The discretion is due to the varied pandemic situations in different localities and their respective capacities of health emergency management. The central government, while constantly emphasizing the strategy of mass social mobilization and instructing local authorities to make full use of digital technologies and big data for early detection of the coronavirus, did not predetermine what digital tools should be used, how to use them, and under what conditions they should be used. The leeway for local improvisation-in other words, the localization of governmental emergency powers-gave rise to the health code. After the initial "success" of the health code in specific cities (success in terms of the speed of development and the scale of implementation), the central government did not dictate other localities to follow the footsteps of Hangzhou and Shenzhen, but only encouraged regions which had sufficient informatization capacities to use the health code (JPCMSC, 2020e).

The lack of specific planification and a certain degree of handsoff attitude of the central government led to the health code's proliferation in China. From Figures 3, 4, we can see that the majority of local health codes were rolled out from mid-February to early March. Many city-based health codes preceded the provincial ones, and some latecomer provinces, like Jiangsu, Hebei, and Jiangxi, took several weeks to "unify" the health codes in their jurisdictions. It is not unreasonable to speculate that this proliferation was also a result of local authorities trying whatever they could and even competing with each other to bring COVID-19 under control, considering the extremely tight political pressure following the sacking of two top officials in Hubei for mismanaging the early outbreak of the epidemic (Kuo, 2020). As will be seen shortly, in contrast with the speedy adoption of the health code in various regions, its takeover by the central government came much later. Given the experimental character of the health code, despite the speed and scale of its use across the country, the actual picture was very messy. As many local authorities introduced their own health code mini apps, the code used in one city or province was often not recognized outside of its jurisdiction. This problem was also attributed to the fact that the data sources, emergency levels, and methodologies of risk assessment were also locally specific. As a result, people traveling across regions for work or study were often required to obtain several health codes in their smartphones or fill in additional questionnaires.

Just as the health code was very much a result of multiple local initiatives, the difficulties incurred by the patchwork were also first addressed at the local level. In late February, provincial governments started signing agreements with each other for the mutual recognition of their health codes. For example, Henan and Zhejiang agreed on February 28th that the Zhejiang health code would be recognized as a health certificate and used in Henan. Since March 1st, Beijing, Tianjin, and Hebei decided to recognize each other's health code to enhance regional, joint anti-COVID efforts. The national level, cross-province recognition of the health codes started in mid-March. On March 18th, the National Integrated Online Government Service Platform offered three ways of interprovince recognition. The first was to introduce the function of interprovince recognition in existing health code programs; the second was to connect existing health codes with the national antiepidemic information platform, using the latter as an intermediary for interprovince recognition; the third way was for regions without local health codes to directly adopt the national health code (Xinhua News Agency, 2020b). Despite these mechanisms, the realization of "free movement with one code" remained slow and difficult. The director of Hangzhou Digital Resources Administration commented in an interview that, below the surface of the technical and standard issues, the real difficulty appeared to be the lack of will and determination of local governments to share data with each other-their "calculation of self-interest" (Xu, 2020). Regions that have been leading the health code program were also unwilling to give up what they had already put in place and switch to the national health code (Xu, 2020), which also explains why the three national standards published in April are only recommendatory. ${ }^{6}$

Therefore, the health code program remains far from being a centrally controlled and nationally uniform system in China. The

${ }^{6}$ The lack of a deeper level of data sharing is a manifestation of the "fragmented authoritarianism.” See Zeng (2020), 8). 

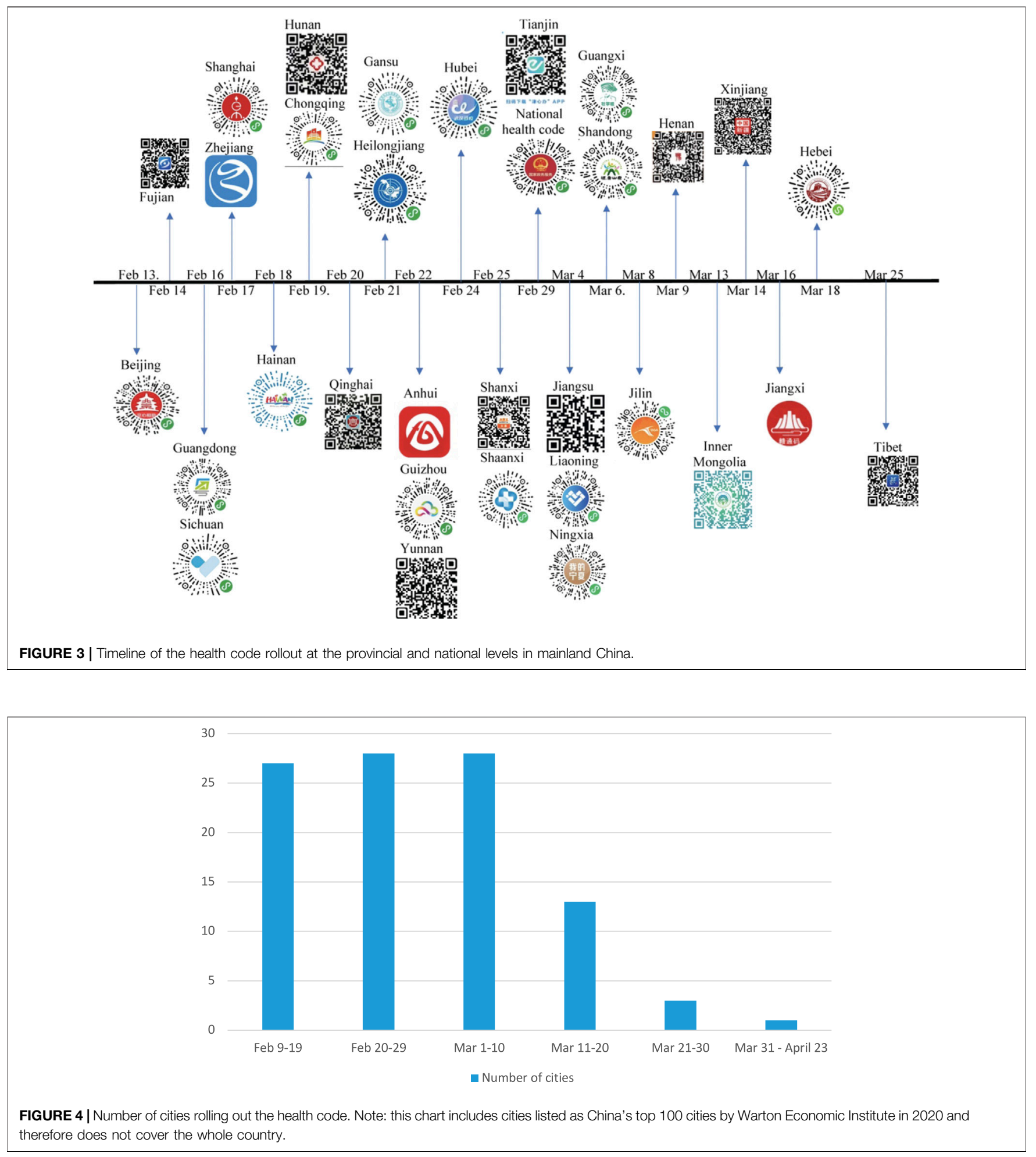

patchwork situation of the health code, along with its regulatory uncertainties, reflects the unease inevitably incurred when a country faces public health emergencies. In the Chinese contexts, the unease is also manifested in the paradox intrinsic to the strategy of mass social mobilization: while encouraging the experimental and entrepreneurial spirit of the local authorities and technology companies to tackle COVID-19, the central government needs to make sure that these efforts appear orderly and are subject to its overall coordination and supervision. The takeover of the health code by the central 
government inevitably faces pushbacks from the local. Maintaining the status quo (i.e., the plethora of the health codes) becomes a way of managing, at least temporarily, the paradox between local agency and central control. The difficulties of regulating the health code may show the state power as less potent, which interestingly contrasts with the earlier discussion about the enhanced power of social ordering and population control during the pandemic. However, these two perceptions are not mutually contradictory but rather demonstrate the state power as variegated and multilayered. From the perspective of individuals using the health code, the relative unruliness of the health code does not change the fact that individuals become more measurable and regulable in various encounters with public and private authorities.

\section{Projecting the Future: From Pandemic Control to Smart Cities}

With the slowdown of COVID-19 in China and the government's emphasis on the "normalization" of epidemic prevention and control, public discussion has turned to the future of the health code in the state governance and public administration, reflecting on the experience from the first half of 2020. A few scholars argue that the health code, as a special tool reacting to the unique needs and conditions of epidemic control, should be terminated and that all the data it collected should be deleted (Yao, 2020). Such a strong stance is only marginal. In mainstream opinions, the health code is deemed as an important opportunity for upgrading governance and public service in a postepidemic society. To grasp this opportunity, mainstream opinions attempt to identify the practical shortcomings of the health code and to address them with policy and legislative proposals. A popular slogan in these discussions goes that "the health code should roam and lengthen its journey" (Dongyuan, 2020). Roaming means that the regional health codes should obtain broader validity beyond respective jurisdictions; lengthening the journey means that this tool should remain in service in a longer term. Such advocacies emphatically allege the ostensible convenience that the health code has brought and will bring to individuals, private and social entities, local communities, and the government. These advocacies, again, do not involve or mention any scientific and empirical studies about the actual effectiveness of the health code in dealing with COVID19. In addition, they often frame the termination of the health code as creating social "wastes," arguing that, since a huge amount of investment has already been made to creating the program and there is no apparent technological hurdle to the expansion of its use, it is more cost-effective to keep using and improving it (Dongyuan, 2020; Lin, 2020).

Such advocacies find some endorsement from the government. In an official instruction on the informatization building of local communities for epidemic control issued on March 5th, the government encouraged the extended development and exploitation of informatization products for community epidemic prevention and control in order to expand functions of urban and rural community governance and public services after the pandemic (Ministry of Civil Affairs et al., 2020). Such endorsement was in line with the relatively hands-off attitude of the central government at the early stage of the health code's adoption and coalesced with the strong commitment of local authorities and the private entrepreneurship driving the program. ${ }^{7}$ Such a favorable policy and political environment created plenty of opportunities for not only function creep but considerable augmentation and transformation of the health code. As mentioned earlier, since late February, the Hangzhou government has already connected the health code to citizens' electronic health cards and social security cards. In Shanghai, the online governmental service platform incorporated the health code mini app in mid-March, connecting it to other public services (Wen, 2020). Since July, the Shanghai health code can also be used as an electronic health insurance card and be linked with users' bank accounts for payment (Liu, 2020). On March 24, the government in Guangzhou claimed that the updated Guangzhou health code would be used as electronic identification and health certificate and that users need to go through facial recognition and real-name authentication to obtain the code (Guo et al., 2020). In Hangzhou, a controversial proposal was made by the government in May to combine the health code with individual health indicators and to collect and analyze the data about citizens' medical records, health checks, and lifestyle management. The three colors would be replaced with a color gradient to represent and rank health indexes of individuals, private and social entities, and local communities (Hangzhou Health, 2020). Having been heavily criticized for its blatant disrespect to individual privacy, the Hangzhou government backed down and claimed that this proposal was just a design idea and needed comprehensive deliberation (Du, 2020; Zhang, 2020b). These initiatives suggest a strong will of the local governments to grasp the momentum of informatization and digitalization created by the health code during COVID-19 to transform governance and to deliver public service in a more efficient, personalized, and precise way. The rationale discussed in the previous section-the meshing between population control and public service in the pandemic-is also normalized by way of highlighting the upgrading of public service to conceal the deepened and more ubiquitous discipline and control over individuals and the population, perpetuating the paternalistic undertone of "technological empowerment" in China.

\section{The Role of Law: Reflecting on Privacy and Data Protection}

The lack of a robust privacy and data protection framework in China is well documented (e.g., Feng, 2019). In the particular context of COVID-19, this legislative deficiency, and accordingly the lack of legal scrutiny, became one of the contributing factors for the fast and large-scale adoption of the health code. The contrast to countries of liberal democracy is remarkable: while in

\footnotetext{
${ }^{7}$ This is consistent with a more general central-local dynamic in developing digital technologies where local and private actors present a major driving force. See Zeng
} (2020), 14-15. 
liberal democracies, privacy and data protection issues are immediately raised in the face of any digital monitoring proposals (understandably, a legacy of the past decade of counterterrorism and privacy advocacy following massive data breaches), such concerns are sidelined in China by the collectivist discourse, such as fighting the "people's war," and only appear in public debates after certain technologies, including the health code, become fait accompli. The out-of-sync between law and technology is not only caused by the different paces of advancement between law and technology commonly observed but also due to China's particular approach to epidemic control which has given local authorities considerable leeway for experimentation and improvisational collaboration with technology companies.

In light of the apparent legislative deficiency, alternative rulemaking in the form of, for example, industrial standards and ad hoc governmental decrees were used to regulate privacy issues. The noncompulsory industrial standards discussed earlier all contain some general requirements on personal information protection. The national standards have made reference to existing regulatory documents, such as China's Cybersecurity Law and the GB/T 35723-2020 Information Security Technology-Personal Information Security Specification. As for ad hoc governmental decrees, an example is the Notice on Protecting Personal Information and Using Big Data to Support the Epidemic Prevention and Control, issued by the Office of the Central Cyberspace Affairs Commission on February $4,{ }^{8}$ in response to several serious incidents of personal information leaks during the COVID-19 outbreak (He, 2020; Cao and Yan, 2020; The Paper, 2020). Personal data protection has also been included in the government's instruction regarding antiepidemic informatization building in local communities. ${ }^{9}$ In light of the fast-evolving antiCOVID situations in China (e.g., the swift proliferation of the health codes), these piecemeal policy documents on privacy and personal data protection remain largely insufficient. Reacting to such deficiencies, traditional law-making efforts began to catch up. This is first reflected by a number of proposals submitted to the National People's Congress and the Chinese People's Political Consultative Conference in late May 2020 regarding the regulation on the use of personal information by digital technologies for pandemic control (Yao, 2020). In addition,

\footnotetext{
${ }^{8}$ It prohibited the collection of personal information by units or individuals other than those authorized under China's Cybersecurity Law, Law on the Prevention and Treatment of Infectious Disease, and Regulation on the Urgent Handling of Public Health Emergencies. The notice stressed the principles of data minimization and purpose limitation and required personal information be published only when necessary and upon data desensitization (Office of the Central Cyberspace Affairs Commission, 2020).

${ }^{9}$ According to this instruction, the collection of residents' information by informatization products (service) of community pandemic control should be explicitly notified to community residents, obtain their consent, and should specify that the data collected would be used for epidemic prevention and control. If the data were to be used for other purposes, consent of community residents should be reobtained. Meanwhile, informatization products should comply with China's Cybersecurity Law, Law on Residential Identity Cards, and other relevant laws and administrative regulations on personal information protection and implement the requirements in the notice issued by the Office of the Central Cyberspace Affairs Commission on February 4 (Ministry of Civil Affairs et al., 2020).
}

there are two recent legislative moves toward regulating digital technologies for the common good. The first is the adoption of China's first Civil Code on May 28, 2020, which contains provisions related to privacy and personal information protection. ${ }^{10}$ The second is the preparation of China's personal information protection law. A draft has now been made and submitted for deliberation by the National People's Congress's Standing Committee in 2020. ${ }^{11}$

The health code has revealed serious challenges of data governance and shortcomings of the existing regulatory framework. These problems, in turn, have encouraged public awareness about privacy and personal data protection and motivated law-making processes to catch up and regulate the use of digital technologies. However, the protection of privacy and personal data provides only one lens to understand the stakes of digital monitoring. Commenting on the controversies over contact tracing apps in the West liberal democracies, Sharon argues that privacy-framing has been taken over by technology companies that present themselves as privacy defenders and meanwhile promote their contact tracing apps, increasingly interfering in the public health sphere (Sharon, 2020). In China, the discourse about privacy and data protection has not been coopted by Chinese technology companies yet, except for Baidu, whose chairman of the board (also a member of the Chinese People's Political Consultative Conference) suggested that opt-out mechanisms should be introduced to information collection during the pandemic and that the collection, storage, and use of personal information under exceptional circumstances should be regulated (Ren, 2020). While Sharon's observation does not echo much in China yet, it points out the unintended consequences of well-meaning privacy advocacy: the discourse of privacy and data protection can potentially provide the terms through which technology companies exercise surveillance and regulatory power and reshape the market, while elbowing aside questions about democracy, accountability, fairness, and justice. Governments are just as capable as private companies of seizing the special conditions of COVID-19 to coopt or hijack the discourse of privacy and personal data protection to strengthen their capacities of administration and control. In China, as the notion of privacy is understood as a personal right and disconnected from its political significance ${ }^{12}$ (e.g., the right to privacy is a political right listed in the International Covenant on Civil and Political Rights, which China has not ratified), current legislative moves toward protecting personal information and individual privacy could be one of the self-justifying steps that align digital technologies with the purpose of enhancing the government's power to control. It is, after all, unsurprising to

\footnotetext{
${ }^{10}$ China's Civil Code, Chapter 6 (National People's Congress, 2020).

${ }^{11}$ One provision in the draft suggests the influence of the pandemic on the lawmaking process. Under Article 13(4), the processing of personal information is allowed when it is necessary to respond to sudden public health incidents or to protect natural persons' lives, health, and property security under emergency circumstances (Legislative Affairs Commission of the Standing Committee of the National People's Congress, 2020).

${ }^{12}$ Privacy is also commonly seen as a consumer right rather than a civil liberty. See Pernot-Leplay (2020).
} 
see a regime exercising sweeping and paternalistic control while claiming to be the guardian of citizens' privacy or diligent fiduciary of personal data.

\section{CONCLUSION}

The health code, like any technology, is socially embedded. It differs significantly from the Gapple contact tracing apps in terms of technical features and legal and political conditions. Its swift development, deployment, and normalization in China are a result of multiple factors, including the external shock of the COVID and the associated political pressure, the government's preexisting and strengthened commitment to datafication and informatization of the society and state governance, Chinese digital platforms' technological leadership and integration in public administration, and the unbalanced development between law and technology in China. As a technology of social ordering and population control, rather than simply contact tracing, it enhances disciplinary power of both public and private authorities by making the health of individuals and the population legible and measurable and creating new ways of intervention for pandemic control. Meanwhile, it is a technology that is subject to and conditioned by various power relationships and becomes relatively unruly, which complicates the picture of "technological empowerment." While this unruliness has pushed new legislative efforts to regulate the health code and better protect individual privacy and personal data, such efforts do not address the technosolutionist assumption of the health code and its implications for state power.

Positioning the health code in such a conjuncture of external shock and China's preexisting sociopolitical conditions, it is a

\section{REFERENCES}

Asdal, K., Brenna, B., and Moser, I. (2007). Technoscience: the politics of interventions (Oslo, Norway: Unipub).

Cao, K., and Yan, J. (2020). 云南警方暂缓拘留泄露确诊患者信息的医务人员 [yunnan police deferred detention of medical staff who leaked patients' information]. People Available at: http://society.people.com.cn/n1/2020/0208/ c1008-31576842.html (Accessed 8, 2020).

Cellan-Jones, R., and Leon, K. (2020). Coronavirus: the great contact-tracing apps mystery Available at: https://www.bbc.com/news/technology-53485569 (Accessed July 21 2020).

Central Committee of the Communist Party of China (2013). 中共中央关于全面 深化改革若干重大问题的决定 [decision of the CCCPC on some major issues concerning comprehensively deepening the reform] Available at: http://www. china.org.cn/chinese/2014-01/17/content_31226494_13.htm.

Chen, B. (2020). 刚性防控”引发的“次生灾害'及其治理 [the secondary disasters of the rigid epidemic prevention and control and their governance]. The Paper Available at: https://www.thepaper.cn/newsDetail_forward_6998254 (Accessed April 17 2020).

China Civil Aviation Administration, and China General Administration of Customs (2020). 中国民用航空局、中华人民共和国海关总署关于中国籍旅客乘坐 航班回国前填报防疫健康信息的公告 [Notice on Chinese citizens returning China by air reporting health information for epidemic prevention]. Available at: http://www.gov.cn/zhengce/zhengceku/2020-04/07/content 5500034.htm.

China Electronics Standardization Institute (2020). 《个人健康信息码》3 3 项国家 标准项目获批立项并征求意见 [three national standards of personal health case about managing public health emergencies and more generally concerned with data-driven governance by which the exceptional situation of a pandemic could be datafied and even rendered just as manageable as other social affairs. In this way, datafication and data-driven governance have the possibility of diffusing the emergency powers of the state by making redundant the line between what is normal and what is exceptional. In addition, as China is making important legislative process on data governance, a likely consequence of data-driven governance would be the merge between the norm and the exception, while personal data are legally protected. In such a circumstance, there would be no ostensible conflicts between individual privacy and public health, and the difficult question about balancing and proportionality that always plagues human rights law would be dissolved (Tsakyrakis, 2009). However, ultimately, this harmonization between individual rights and public interests remains subjected to the paternalistic state power.

\section{DATA AVAILABILITY STATEMENT}

The original contributions presented in the study are included in the article/Supplementary Material; further inquiries can be directed to the corresponding authors.

\section{AUTHOR CONTRIBUTIONS}

The author confirms being the sole contributor of this work and has approved it for publication.

information code are initiated and soliciting opinions]. Available at: http:// www.cesi.cn/202004/6363.html (Accessed April 20 2020).

Chinese National Standardization Administration (2020a). 国家标准化管理委员 会关于下达《个人信息码 参考模型》等6项推荐性国家标准计划的通知 [Notice of national standardization administration on issuing six recommendatory national standards, including the "personal health information code - reference model"] Available at: http://www.samr.gov.cn/ bzjss/tzgg/202004/P020200420579795284435.pdf.

Chinese National Standardization Administration (2020b). 个人健康信息码参考 模型 [personal health information code - reference model].” GB/T 38961-2020. Beijing, China: National Standardization Administration.

Chinese National Standardization Administration (2020c). 个人健康信息码 应用 接口 [personal health information code - application interface].” GB/T 38963 2020. Beijing, China: National Standardization Administration.

Chinese National Standardization Administration (2020d). 个人健康信息码 数据 格式 [personal health information code - data format]GB/T 38962-2020. Beijing, China: State Administration of Market Regulation \& Chinese National Standardization Administration.

Beijing Daily (2020). 所有外省市返京人员 一律居家或集中观察14天 [all travelers to beijing to Be subjected to self or collective quarantine for 14 days]. Xinhua Available at: http://www.xinhuanet.com/2020-04/01/c 1125796509.html (Accessed April 1 2020).

China Daily (2020). China's Fight Against COVID-19. Institute of contemporary China studies. Tsinghua University, and School of Health Policy and Management, Peking Union Medical College. Available at: http://www. chinadaily.com.cn/pdf/2020/Chinas.Fight.Against.COVID-19-0420-final2.pdf. 
Davis, K., Fisher, A., Kingsbury, B., and Engle Merry, S. (2012). Governance by indicators: global power through classification and rankings. Oxford, United Kingdom: OUP.

Dongyuan (2020). 健康码要“漫游”也要“长游” [health code should roam and lengthen its journey]. Beijing Youth Daily (Accessed March 26, 2020).

Du， H. (2020). “杭州推行渐变色健康码，涉嫌侵犯市民隐私 [suspected violations of citizen' privacy of Hangzhou color-changing health code] Available at: https://www.sohu.com/a/397531243_665455 (Accessed May 25, 2020).

Feng, Y. (2019). The future of China's personal data protection law: challenges and prospects. Asia Pac. L. Rev. 27 (1), 62-82. doi:10.1080/10192557.2019.1646015

Foucault, M. (1995). Discipline and punish: the birth of the prison. New York, NY: Vintage Books.

Foucault, M. (2007). Security, Territory, Population: lectures at the College de France, 1977-1978. Basingstoke; NY: Palgrave Macmillan: République Française.

Fraser, C., Abeler-Dörner, L., Ferretti, L., Parker, M., Kendall, M., and Bonsall, D. (2020). Digital contact tracing: comparing the capabilities of centralised and decentralised data architectures to effectively suppress the COVID-19 epidemic whilst maximising freedom of movement and maintaining privacy Available at: https://github.com/BDI-pathogens/covid-19_instant_tracing.

Guan, T., Xue, L., and Zhao, J. (2019). 技术赋能的治理创新:基于中国环境领域 的实践案例 [Technology-Enabled governance innovation: an empirical study of China's environmental action]. Chin. Public Adm. 2019 (4), 58-65. doi:10. $1155 / 2019 / 4629457$

Guo, S., Huang, S., and Wu, W. (2020). “新穗康码来了! 将作为电子身份证, 或用 于地铁公交 [new sui kang ma as electronic ID may Be used in public transport]. Southcn 24, 2020, 2020 Available at: http://news.southcn.com/ gd/content/2020-03/24/content_190636482.html.

Haikou Education Department (2020). 海口市教育局2020年面向全国公开招聘 直属单位(含学校、幼儿园)工作人员公告 [announcement of haikou education department on recruitment of subordinated unites (including schools and kindergartens)]. Education Department of Haikou City. Available at: http://jyj.haikou.gov.cn/edu/tripage!content.action?tri. id=6724313 (Accessed July 18 2020).

Hangzhou Daily (2020a). 市疫情防控工作领导小组召开专题会议 [special conference of the city's anti-COVID working group]. Hangzhou, China: Hangzhou People's Government. Available at: http://www.hangzhou.gov.cn/ art/2020/2/7/art_812258_41886422.html (Accessed February 7, 2020).

Hangzhou Daily (2020b). 特定行业亮码上岗 杭州健康码新增电子健康证应用 [health code scanning for designated professions, Hangzhou health code adds electronic health certificate] Available at: http://zj.sina.com.cn/news $/ \mathrm{m} / 2020$ 04-15/detail-iircuyvh7732858.shtml (Accessed April 15, 2020).

Hangzhou Fabu (2020). 杭州健康码又出新功能! 心理援助” 护佑市民群众 心 理健康'! hangzhou health code has a new function: "psychological assistance" protects people's psychological wellbeing]. The Paper Available at: https://m. thepaper.cn/newsDetail_forward_7177346 (Accessed April 28, 2020).

Hangzhou Health (2020). 集众力 汇众智 市卫健委全力深化杭州健康码常态 化应用 [gather people's power and wisdom: municipal health commission deepens the normalization of Hangzhou health code's application]. Hangzhou Municipal Health Commission Available at: http://wsjkw.hangzhou.gov.cn/art/ 2020/5/23/art_1229113672_47550183.html (Accessed May 23, 2020).

Hangzhou Market Regulation Administration (2020). 杭州健康码管理与服务 指南 [guide to management and service of Hangzhou health code] DB 3301/T 0305-2020. Hangzhou, China: Hangzhou Market Regulation Administration.

He, C. (2020). 海量涉疫情个人信息泄露 两地公安做出行政拘留处罚 [public security departments impose administration detention following massive personal information leaks] Available at: https://news.sina.com. cn/o/2020-02-05/doc-iimxyqvz0398976.shtml (Accessed February 5, 2020).

Hinch, R., Probert, W., Nurtay, A., Kendall, M., and Wymant, C. (2020). Effective configurations of a digital contact tracing app: a report to nhsx Available at: https://github.com/BDI-pathogens/covid-19_instant_tracing.

Ienca, M., and Vayena, E. (2020). On the responsible use of digital data to tackle the COVID-19 pandemic. Nat. Med. 26 (4), 463-464. doi:10.1038/s41591-020$0832-5$

Jasanoff, S. (2004). States of knowledge: the Co-production of science and social order. London; New York: International Library of Sociology.
Jasanoff, S (2017). Virtual, visible, and actionable: data assemblages and the sightlines of justice. Big Data Soc. 4 (2), 1-15. doi:10.1177/2053951717724477

Jiao, Y., Wang, H., Su, Q., and Zhang, M. (2020). “健康码: 人员流动的健康保障 [health code: health safeguard of human movement]. The Paper Available at: https://www.thepaper.cn/newsDetail_forward_6877828 (Accessed April 9, 2020).

JPCMSC (2020a). 关于加强新型冠状病毒感染的肺炎疫情社区防控工作的通 知 [Notice on Strengthening Community Work of Preventing and Controlling the Novel Coronavirus Pneumonia] Available at: http://www.gov.cn/xinwen/ 2020-01/26/content_5472235.html.

JPCMSC (2020b). 关于切实为基层减负全力做好新型冠状病毒感染的肺炎疫 情防控工作的通知 [notice on practically alleviating local burdens, going allout for COVID-19 prevention and control] Available at: http://www.nhc.gov. $\mathrm{cn} / \mathrm{jws} / \mathrm{s} 7874 / 202002 / \mathrm{b} 2 \mathrm{~b} 06414 \mathrm{c} 0 \mathrm{f} 44 \mathrm{e} 1 \mathrm{db} 28 \mathrm{~d} 56 \mathrm{e} 11044 \mathrm{ba3b} . s h t m l$.

JPCMSC (2020c). 关于进一步强化责任落实, 做好防治工作的通知 [Notice on strengthening responsibility implementation for the prevention and treatment of the coronavirus] Available at: http://www.gov.cn/zhengce/2020-02/07/ content_5475951.htm.

JPCMSC (2020d). 国务院联防联控机制印发通知要求切实加强疫情科学防控 有序做好企业复工复产工作 [notice on strengthening scientific epidemic prevention and control and resuming work and production in order] Available at: http://www.gov.cn/xinwen/2020-02/09/content_5476550.htm.

JPCMSC (2020e). 国务院应对新型冠状病毒肺炎疫情联防联控机制关于依法 科学精准做好新冠肺炎疫情防控工作的通知 [notice on preventing and controlling the novel coronavirus pneumonia scientifically and in accordance with the law] Available at: https://app.www.gov.cn/govdata/gov/ 202002/26/455180/article.html.

Kofler, N., and Baylis, F. (2020). Ten reasons why immunity passports are a bad idea. Nature 581 (7809), 379-381. doi:10.1038/d41586-020-01451-0

Kuo, L. (2020). China fires two senior Hubei officials over coronavirus outbreak. The Guardian Available at: https://www.theguardian.com/world/2020/feb/11/ china-fires-two-senior-hubei-officials-over-coronavirus-outbreak (Accessed February 11, 2020).

Lee, A. (2020). If Bluetooth doesn't work for contact-tracing apps, what will?. Wired Available at: https://www.wired.co.uk/article/bluetooth-contact-tracingapps (Accessed April 17, 2020).

Legislative Affairs Commission of the Standing Committee of the National People's Congress (2020). Personal information protection law of the people's Republic of China (draft) [中华人民共和国个人信息保护法(草案)] Available at: https://www.dataguidance.com/sites/default/files/china_draft_personal_data_ law.pdf.

Lin, J. (2020). 延展健康码功能 不妨给用户一点选择权 [expanding health code's functions, why not give users some choices]. Natl. Business Daily. Available at: http://www.nbd.com.cn/articles/2020-05-27/1439484.html (Accessed May 27, 2020).

Liu, X. (2020). “随申码”改版升级 实现“一码”就医 [sui shen ma update for receiving medical treatment]. Youth (Accessed July 7, 2020).

Lyon, D. (2005). Surveillance as social sorting: privacy, risk and automated discrimination. Florence: Taylor \& Francis. Available at: http://public.eblib. com/choice/publicfullrecord.aspx? $\mathrm{p}=240591$.

Mello, M. M., and Wang, C. J. (2020). Ethics and governance for digital Disease surveillance. Science 368 (6494), 951-954. doi:10.1126/science.abb 9045

Milan, S. (2020). Techno-solutionism and the standard human in the making of the COVID-19 pandemic. Big Data Soc. 7 (2), 1-7. doi:10.1177/ 2053951720966781

Ministry of Civil AffairsCyberspace Administration of ChinaMinistry of Industry and Information TechnologyNational Health Commission (2020). 新冠肺炎疫 情社区防控工作信息化建设和应用指引 [instruction on the informatization building of community epidemic prevention and control] Available at: http:// www.gov.cn/zhengce/zhengceku/2020-03/05/content_5487110.html.

Morley, J., Cowls, J., Taddeo, M., and Floridi, L. (2020). Ethical guidelines for COVID-19 tracing apps. Nature 582 (7810), 29-31. doi:10.1038/d41586-020-01578-0

National People's Congress (2020). Civil code of the people's Republic of China. PRC presidential order, 45 , 2020 Available at: http://www.npc.gov.cn/npc/ c30834/202006/75ba6483b8344591abd07917eld25cc8.shtml.

Office of the Central Cyberspace Affairs Commission (2020). 关于做好个人信息 保护利用大数据支撑联防联控工作的通知 [notice on protecting personal information and using big data to Support the epidemic prevention and 
control]. Available at: http://www.gov.cn/xinwen/2020-02/10/content_ 5476711.html.

Pernot-Leplay, E. (2020). China's approach on data privacy law: a third way between the U.S. And the E.U.?. Penn State. J. L. Int. Aff. 8 (1), 49-117.

Privacy Guardians (2020). 超7000武汉公民信息泄露之后 [more than 7000 wuhan citizens' personal details leaked]. Privacy Guardians. January 27, 2020, 2020 Available at: http://mp.weixin.qq.com/s?_biz=MjM5NDAyNTQy $\mathrm{MQ}==\& \mathrm{mid}=2649156448 \& \mathrm{id} \mathrm{x}=1 \& \mathrm{sn}=10 \mathrm{~b} 6 \mathrm{dce} 70 \mathrm{f} 8 \mathrm{e} 4006170 \mathrm{e} 2 \mathrm{ca} 73 \mathrm{ce} 87 \mathrm{f} 6 \mathrm{f} \& \mathrm{c}$ hksm=be9c51c289ebd8d48b95798a4650a85fe3b0ed934633d4e900b6d8560b4b $128 \mathrm{a} 4688018 \mathrm{c} 278 \mathrm{f} \# \mathrm{rd}$.

Ran, H. (2019). The grid governance in perspective of the grassroots social governance: innovation, challenge and solutions. Governance Modernization Stud. 2019 (1), 74-79.

Ren, X. (2020). 李彦宏建议针对疫情采集的个人信息设立退出机制 $[\mathrm{Li}$ yanhong suggests creating opt-out mechanisms for information collected during epidemic]. The Econ. Observer, Available at: http://m.eeo.com.cn/ 2020/0521/384268.shtml (Accessed May 21 2020).

Scott, J. (1999). Seeing like a state: how certain schemes to improve the human condition have failed. London, United Kingdom: Yale University Press.

Scott, M., Braun, E., Delcker, J., and Manancourt, V. (2020). How Google and Apple outflanked governments in the race to build coronavirus apps. Politico Available at: https://www.politico.eu/article/google-apple-coronavirus-appprivacy-uk-france-germany/ (Accessed May 15 2020).

Shanghai Bendibao (2020). 随申码'再升级, 扫这个码即可验证!企业个人均可 申请 [Sui shen ma updates, verification upon scanning, open for company and individual application]. Available at: https://wemp.app/posts/193bfe47-e3f548e5-9400-94d9aa0b2ee0 (Accessed March 16 2020).

Sharon, T. (2020). Blind-Sided by privacy? Digital contact tracing, the apple/google API and big tech's newfound role as global health policy makers. Ethics and Information Technology, 1-13. doi:10.1007/s10676-020-09547-x

Shenzhen Standards Promotion Council (2020). 防疫通行码参考架构与技术指 南 [reference architecture and technology guide of anti-epidemic pass code]. T/SZS 4010-2020. Association Standards of Shenzhen Standards Promotion Council. Shenzhen Standards Promotion Council. Available at: http://www. echinagov.com/info/280621.

Song, M., and Xu, Y. (2020). 擅自封路是“硬核抗疫”?违法乱为不可纵 [directing industries to strengthen confidence, to be accountable and fulfill the duty of defending the territory]. Qi Zhi, Available at: http://www.qizhiwang.org.cn/n1/ 2020/0320/c431674-31641706.html (Accessed March 20, 2020).

Sun, F. (2020). 擅自封路是“硬核抗疫'?违法乱为不可纵! [Unauthorized blocking roads as "hardcore anti-coronavirus"? No indulgence towards violations of law]. Xinhua Available at: http://www.xinhuanet.com/politics/ 2020-01/29/c_1125509195.html (Accessed January 29, 2020).

Tang, M., Chen, R., and Jiang, C. (2020). 有效发挥城乡社区在疫情防控全局中 的基础性地位 [let urban and rural communities effecitvely play a fundamental role in the epidemic prevention and control]. Available at: http://mzzt.mca.gov. cn/article/zt_2020yqfkzjz/gzjs/sqfk/202004/20200400026539.shtml.

Taylor, L., Sharma, G., Martin, A., and Jameson, S. (2020). Data justice and COVID-19: global perspectives (London, United Kingdom: Meatspace Press.) Available at: https://ia801504.us.archive.org/25/items/data-justice-and-covid19/Data_Justice_and_COVID-19.pdf.

The Paper (2020). 疫情防控, 网警在行动![COVID-19 prevention and control, cyber police in operation]. The Paper Available at: https://www.thepaper.cn/ newsDetail_forward_5756855 (Accessed February 9, 2020).

Tsakyrakis, S. (2009). Proportionality: an assault on human rights?. Int. J. Constitutional L. 7 (3), 468-493. doi:10.1093/icon/mop011

Veale, M. (2020). "Sovereignty, privacy and contact tracing protocols," in In data justice and COVID-19: global perspectives. Editors L. Taylor, G. Sharma,
A. Martin, and S. Jameson (London, United Kingdom: Meatspace Press), 34-39.

Wen, H. (2020). 上海“一网通办'升级 ‘随申码’, 为企业负责人开放了一个'特殊 通道' [Shanghai updates sui shen ma on one-stop online governmental service, providing enterprises A special passage] Available at: www.sohu.com/a/ 380331161_120244154 (Accessed March 15, 2020).

Xiang, B. (2020). Point-to-Point labour transport: the post-lockdown securitization of mobility. COMPAS Available at: https://www.compas.ox.ac.uk/2020/point-topoint-labour-transport-the-post-lockdown-securitization-of-mobility/ (Accessed April 22, 2020).

Xiaoshan (2020). 武汉肺炎致湖北人鼠年受歧视如过街老鼠 [the coronavirus pneumonia led discrimination against Hubei people during the Chinese new year]. RFI Available at: http://www.rfi.fr/cn/中国/20200130-武汉肺炎致湖北 人鼠年受歧视如过街老鼠 (Accessed January 30, 2020).

Xinhua News Agency (2020a). 全总倡议: 广大职工为做好疫情防控工作贡献智 慧和力量 [all-China federation of trade unions calls for workers' contribution to epidemic prevention and control]. The state Council, the people's Republic of China. Available at: http://www.gov.cn/xinwen/2020-01/27/content_5472552. htm (Accessed January 27 2020).

Xinhua News Agency (2020b). 依托全国一体化政务服务平台共享信息 全国绝 大部分地区'健康码'已可实现 “一码通行' [sharing information through national integrated online government service platform: health codes of most localities have realized "free movement with one code"] Available at: http://www.gov.cn/xinwen/2020-03/21/content_5494037.htm (Accessed March 21 2020)

$\mathrm{Xu} ， \quad$ D. (2020). 健康码遭层层 ‘加码’ 全国范围互认真的这么难吗? [The multiplication of health code, is nation-wide recognition really so difficult?. News China, Available at: http://www.chinanews.com/gn/2020/04-28/9170116. shtml (Accessed April 27 2020).

Yao, J. (2020). “疫情后, 健康码可否升级“全能码”? [can the health code become "omnipotent" after COVID-19?]. Caijing, Available at: http://news. caijingmobile.com/article/detail/417535?source_id=40 (Accessed June 8 2020).

Zastrow, M. (2020). "Coronavirus contact-tracing apps: can they slow the spread of COVID-19?. Nature. doi:10.1038/d41586-020-01514-2

Zeng, J. (2020). Artificial intelligence and China's authoritarian governance. International Affairs TBD (TBD). Available at: https://academic-oup-com.eui. idm.oclc.org/ia/advance-article/doi/10.1093/ia/iiaa172/5922010?searchresult=1.

Zhan, Z. (February 23). 杭州健康码宣布升级杭州市民可凭支付宝健康码看病 [Hangzhou health code updates, citizens can receive medical treatment with AliPay health code]. Techweb Available at: http://m.techweb.com.cn/article/ 2020-02-23/2778341.shtml.

Zhang, L. (2020a). When platform capitalism meets petty capitalism in China: Alibaba and an integrated approach to platformization. Int. J. Commun. 14, 114-134.

Zhang, L. (2020b)，杭州市卫健委回应“渐变色健康码” [Hangzhou health commission's response on color-changing health code]. The Paper Available at: https://www.thepaper.cn/newsDetail_forward_7579606 (Accessed May 25, 2020).

Conflict of Interest: The author declares that the research was conducted in the absence of any commercial or financial relationships that could be construed as a potential conflict of interest.

Copyright $(2021$ Cong. This is an open-access article distributed under the terms of the Creative Commons Attribution License (CC BY). The use, distribution or reproduction in other forums is permitted, provided the original author(s) and the copyright owner(s) are credited and that the original publication in this journal is cited, in accordance with accepted academic practice. No use, distribution or reproduction is permitted which does not comply with these terms. 